\title{
Modelling the Impact of World Bank Policy-Based Lending: The Case of Malawi's Agricultural Sector
}

\author{
JANE HARRIGAN
}

This article uses a multi-market agricultural pricing model to analyse the impact of the World Bank's three structural adjustment loans (SALs) to Malawi on the smallholder agricultural sector. Three price policy scenarios are simulated on the model representing zero, partial and full compliance with the Bank'S SAL price policy conditionality. These scenarios are analysed in terms of their impact on: the government budget; smaltholder real incomes; maize production; exportable cash crop production; and the balance of payments. Critiques of the Bank's programme and the government and Bank bargaining strategies are assessed in the light of the modelling results.

\section{INTRODUCTION}

Since the early 1980 s the World Bank has supported structural adjustment programmes in a large number of developing countries. Such programmes consist of loans to support the balance of payments along with attached policy conditions designed to restore sustainable medium term growth. SubSaharan Africa has been a major recipient of such loans. Between 1980 and 1992 a total of 38 Sub-Saharan countries implemented structural adjustment programmes with the World Bank providing $\$ 7.1$ billion in financial support [Kraaij, 1994: 252-7].

Most of the adjustment programmes in Sub-Saharan Africa focused heavily on reforming and restoring growth in one of the region's key tradable goods sectors, namely, agriculture [Mosley, 1987: 5]. Despite this, very little work has been done to model formally the impact of World Bank

Jane Harrigan, School of Economic Studies, University of Manchester, Oxford Road, Manchester, M13 9PL, Tell: (0161) 275-4837, Fax: (0161) 275-4928, E-mail: Jane.Harrigan@ man.ac.uk 
policy-based lending on Sub-Saharan agriculture, either by the Bank itself or by independent researchers." This article attempts to rectify this by using a multi-market agricultural pricing model to quantify the impact of a structural adjustment programme in one particular country, namely, Malawi. In so doing it offers quantitative support to the critique of Malawi's World Bank-supported agricultural adjustment programme.

Attempts to evaluate the impact of World Bank structural adjustment programmes have utilised one of three techniques: the 'before versus after' technique, as in World Bank [1994], which compares actual outcomes during and after adjustment with outcomes in a previous period; the 'plan versus actual' method [Harrigan, 1995; Chalira, 1993], which compares actual outcomes with expected outcomes; and the 'with versus without' method [Mosley, Harrigan and Toye, 1991, Vol.1: World Bank, 1988], which compares actual outcomes with a counter-factual representing what would have happened in the absence of the adjustment programme. It is generally agreed that the 'with versus without' methodology is the superior of the three since it overcomes the difficulty of extraneous factors intervening in the programme period and the problem of the appropriate specification of programme targets. ${ }^{2}$

Using models to evaluate the impact of a structural adjustment programme represents an application of the 'with. versus without' methodology. The adjustment policies pursued by at country can be simulated on a model and the results compared to the simulation of hypothetical counter-factual policy scenarios which represent the policies that would have been followed in the absence of the adjustment programme. This study reports the results of such an evaluation exercise applied to Malawi's smallholder agricultural sector.

\section{MALAWI'S STRUCTURAL ADIUSTMENT PROGRAMME}

Between 1981 and 1987 Malawi received three Structural Adjustment Loans (SA.Ls) from the World Bank which provided US\$167 million in balance of payments support. ${ }^{3}$ The reform package attached to these loans focused heavily on the smallholder agricultural sector and used adjustments in agricultural prices as the main policy instrument to stimulate growth in the sector. ${ }^{4}$ The price reforms were implemented through the monopsonistic state marketing board, the Agricultural Development and Marketing Board (ADMARC). Prior to the adjustment programme the government had used ADMIARC to tax heavily smallholder production of export crops (tobacco, groundinuts and cotton) and used part of the revenue to subsidise production of food crops such as maize and rice [Harrigan, 1988; Kydd and Christiansen, 1982]. Smallholder agricultural inputs such as fertiliser and 
seed were also heavily subsidised as part of the drive to improve the country's food self-sufficiency.

The Bank's adjustment programme in Malawi aimed to reverse previous policies in three ways: ADMARC's prices for smallholder exports crops were raised towards farmgate export parity levels; the price of maize was held constant in order to suppress the relative producer price for food crops; and subsidies on agricultural inputs were gradually removed. The aim was two fold: to stimulate smallholder production of export crops so as to generate export-led growth; and to remove price distortions in the sector so as to achieve improved allocative efficiency.

By the late 1980s the Bank's agricultural policy configuration in Malawi was under attack [Harrigan, 1988; Lele, 1988; Chrisiansen and Southworth, 1988; Cromwell, 1992]. The main thrust of the critique was that deep-seated structural constraints in the smallholder sector were such that the sector was unable to respond adequately to the price incentives of the adjustment programme. Rather than eliciting an increase in aggregate smallholder output the introduction of export parity prices had resulted in exportable cash crops replacing food crops in the production pattern with adverse food security implications. This had been exacerbated by the removal of input subsidies which had reduced the growth of smallholder fertiliser uptake and discouraged the production of fertiliser responsive improved maize varieties. In addition, expecting ADMARC to pay trade parity prices had caused the marketing board to face a cash flow crisis which placed demands on the Central Govemment budget and contributed to a collapse in the formal marketing system [Harrigan, 1988]. The eventual need for maize imports also had adverse balance of payments effects and some analysts argued that smallholder welfare had also deteriorated [Pryor, 1990, Sahn et al, 1990]. The structuralist view was that non-price policies were needed to address structural constraints ${ }^{5}$ and stimulate increases in aggregate output so that export crops could be produced by smallholders without jeopardising food security.

\section{THE MODEL'S STRUCTURE}

Due to the increasing importance of agricultural pricing issues in the early 1980 s in both project and programme lending the Bank felt it necessary to improve upon the methods used for the analysis of price policy [World Bank, 1984a; 1984b]. In particular, the policy dialogue between Bank staff and goverments stood in need of 'appropriate analytical methods that would allow us to trace the impact of complex policy recommendations on a number of government objectives in explicit and quantitative terms' [World Bank, 1984a: 4]. One such analytic method was modelling work. 
In 1983 Malawian data were applied to a prototype model to develop a reduced form multi-market model of Malawi's smallholder agricultural sector. The model incorporated special features of Malawi's agricultural sector - three agro-economic regions, the dominance of ADMARC, panterritorial and pan-seasonal pricing of smallholder crops and inputs, and the importance of subsistence in smallholder production.

The impact of various policy instruments on multiple indicators could be quantified [World Bank, 1983; 1984c, 1984d; Kirchner, Singh and Squire, 1985]. These indicators include: agricultural production, consumption and resource allocation (reflecting the efficiency objective); income distribution (reflecting equity and welfare objectives); agricultural self-sufficiency; agricultural imports and exports (reflecting the external balance objective); and Government budgets both directly and indirectly via ADMARC accourits.

The multi-market model built upon the tradition of farm-household models which incorporate both production and consumption decisions [Yotopoulos and Lau, 1974; Barnum and Squire, 1979; Ahn, Singh and Squire, 1981]. Supply and consumption responses were derived from underlying production and utility functions in which optimisation and technology choice were treated implicitly. Responses to exogenous price changes were first calculated at the micro level of the representative household and then aggregated to generate responses at the market level [World Bank, 1984b].

The model invokes the assumption that smallholder farmers, on average, tend towards a profit maximising solution, subject to three constraints: satisfying subsistence consumption requirements; technological possibilities and fertiliser availability. Hence, it is assumed that a representative farmer attempts to maximise the following:

$$
\operatorname{Max} \Pi=\sum_{i}^{n} P_{i} Y_{i} A_{i}-(R+W) \sum_{i}^{n} F_{i} A_{i}-C
$$

Where: $\Pi=$ total farm profits from production of various crops

$i-n=$ the following crops:

unfertilised local maize

fertilised local maize

composite maize

hybrid maize

tobacco

groundnuts

cotton

rice

$P_{i}=$ crop price

$Y_{i}=$ crop yield per unit of land 


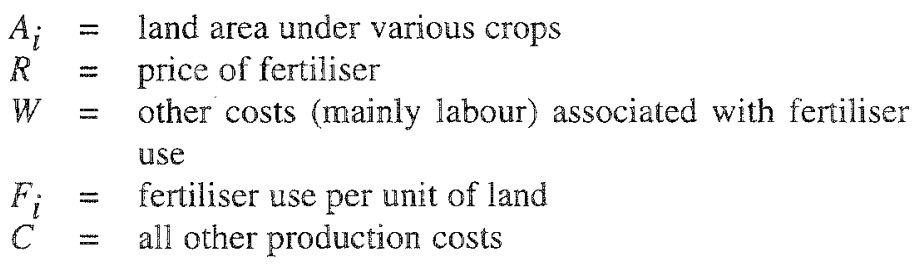

The technological possibilities constraints take the form of fertiliser response functions:

$$
Y_{i}=a_{i}+b_{i} F_{i}-c_{i} F_{i}^{2}
$$

Where: $a_{i}, b_{i}, c_{i}$ are parameters.

The constraint on the representative farmer's total fertiliser use, which results from the Smallholder Feriliser Revolving Fund's (SFRF) fertiliser import supply programme, is specified as:

$$
\sum_{i}^{n} F_{i} A_{i} \leq \bar{F}
$$

Where: $\bar{F}$ is the quantity of fertiliser available to the representative farmer. The value of $\bar{F}$ is determined by the total amount of fertiliser imported for the smallholder sector minus leakages outside the sector divided by the total number of smallholders. Leakages are given by a leakage function which captures the amount of fertiliser sold unofficially by smallholders to estates. This leakage results from the difference between ADMARC's subsidised fertiliser price (ADMARC sells fertiliser to smallholders on behalf of the SFRF) and the price at which estates can buy fertiliser from the commercia! company Optichem. The leakage function is specified as:

$$
L=M\left[\theta_{1}+\theta_{2}(\hat{R}-R)^{\beta}-\theta_{3}\left(\sum_{i}^{n} P_{i}\right)^{\alpha}\right]
$$

Where: $L=$ leakage to estates

$M=$ total SFRF fertiliser imports

$p_{i}=$ smallholder crop prices

$R=$ ADMARC's fertiliser price

$\hat{R}=$ Optichem's fertiliser price

$\theta_{1}, \theta_{2}, \theta_{3}, \beta, \alpha$ are parameters

Hence, $\bar{F}=\frac{M-L}{\text { total smallholders }}$

A third constraint exists in the form of a subsistence consumption requirement for" local maize. The fact that Malawian smallholders grow local maize primarily for own-consumption, and hybrid and composite maize for sale, means that the profit maximising motive only applies to 
hybrid and composite varieties. The subsistence constraint takes the form of:

$$
Y_{1} A_{1}+Y_{2} A_{2} \geq \bar{C}
$$

Where: $Y_{1} A_{1}=$ production of fertilised local maize

$Y_{2} A_{2}=$ production of unfertilised local maize

$\vec{C}=$ minimum consumption requirement

In all simulations the subsistence constraint is binding.

The amnount of fertiliser, $F_{1}$, used on local maize, can be derived directly from equations (2) and (6). The amount of fertiliser available for other crops is therefore:

$$
\bar{F}-A_{1} F_{1}
$$

and its allocation is determined by the profit maximising solution, subject to the technological constraints and the revised constraint on fertiliser availability. The solution gives the following set of demand curves for fertiliser use on all crops other than local maize:

$$
F i=\left[\frac{1}{2 c_{i}}\right]\left[\frac{R+\lambda}{\left[b_{i}-P_{i}\right]}\right] i=2,, n
$$

$\lambda$ is the Lagrangian multiplier on the constraint defining fertiliser availability. The value of $\lambda$ corresponds exactly to the scarcity premium on fertiliser i.e, the extent to which the true value exceeds market price. The model determines the value of $\lambda$ as a function of $\bar{F}$. Equation (7) possesses all the usual properties of a demand curve.

Equations (1) to (7) form the core equations of the model. Once the model has been solved for a particular set of prices $\left(R\right.$ and $\left.P_{i}\right)$ and fertiliser imports $M$, information can be obtained regarding the impact of the price package on variables of relevance to government policy objectives, such as total fertiliser use, total crop production, changes in farm profits and smallholder income.

The budgetary cost of a particular price and import policy package, in terms of input trading activities, can also be assessed:

$$
N F E=\left[\sum_{i}^{n} F_{i}+L\right](R-C)-M X-A
$$

Where: $N F E=$ net profits/loss on SFRF's fertiliser trading account

$$
\begin{aligned}
\sum_{i}^{n} F_{i}+L & =\text { ADMARC's total fertiliser sales } \\
R & =\text { ADMARC fertiliser selling price } \\
C & =\text { average transport and handling costs } \\
M & =\text { quantity of SFRF's fertiliser imports } \\
X & =\text { cost of fertiliser imports } \\
A & =\text { overheads associated with fertiliser trading }
\end{aligned}
$$


The model also calculates ADMARC's net profits/losses from various crop trading activities. This depends on total procurement, ADMARC's purchase prices, domestic demand and domestic selling prices, export demand and export selling prices, transport and handling costs and overheads. For example, assuming all maize procurements are sold for domestic consumption:

$$
N P M=Q(\hat{P}-P-D)-A
$$

Where: $N P M=$ net profit/loss on maize account

$\hat{P}=$ ADMARC maize selling price

$P \quad=$ ADMARC maize buying price

$T \quad=$ average transport and handling costs

$Q \quad=$ total maize procurement

$A=$ overheads associated with maize trading

Maize procurement is estimated as follows:

$$
Q=\sum_{i=1}^{4} Y_{i} A_{i}-\bar{C} Z
$$

Where: $\sum_{i=1}^{4} Y_{i} A_{i}=$ total production of fertilised local maize, unfertilised local maize, hybrid maize and composite maize

$\bar{C} \quad=$ subsistence consumption per smallholder

$Z \quad=$ number of smallholders

For all other crops, procurement is assumed to equal total production.

The total budgetary cost of a given fertiliser supply and input and output price package, that is, SFRF's net revenue/loss on input trading and ADMARC's net revenue/loss on crop trading is:

$$
R=N F E+N P M+N P O
$$

Where: $N P O=$ net revenue/loss on all non-maize crop trading.

The model calculates the change in revenue for alternative policy scenarios:

$$
\Delta R=R_{1}-R_{0}
$$

Where $R_{0}=$ revenue in base case

$R_{1}=$ revenue in policy simulation

Assumptions regarding minimum and maximum ADMARC procurement requirements can also be used to calculate the revenue effects of a policy package in terms of maize imports and stock run-down, or maize exports and stock accumulation. Combining this information with the model's estimates of export crop production enables derivation of the balance of payments effects of different price policies. 
Before the model can be used it must first be calibrated using base-year initialisation data. For example, if the model is to be used to analyse different price policy proposals for the 1995/96 growing season, it will be recalibrated using the most recent data, that is, data from the 1994/95 season. This recalibration exercise involves editing the basic programme by entering base-year data. In addition a weather index for the prediction year and a complete set of crop price elasticities (both own-price and cross-price) must be specified. The model then derives a calibration constant from data on base year prices and production, and uses this constant in policy simulations for the prediction year. The weather index and elasticity paranneters were derived using an iterative process. Different indices and elasticities were used to predict production for the years 1982/83-1985/86. The predictions were compared with the actual production in the years in question. A recursive process of elasticity and index revision was then carried out until the difference between the predicted and the actual outcomes was minimised, whilst still preserving elasticities in the range reported in studies done elsewhere. The revised own-price and cross-price supply elasticities are presented in Table 1. With the final derived parameters the model performs well in terms of predicting outcomes.

TABLE 1

ELASTICITIES USED IN THE MODEL

Price Elasticities

\begin{tabular}{lcccccccc} 
Crop & GN & RI & CT & TO & UM & FM & IM & FR \\
\hline GN & 0.85 & 0.85 & 0.00 & -0.01 & -0.04 & -0.20 & -0.26 & -0.20 \\
RI & 0.00 & 0.66 & 0.00 & 0.00 & -0.08 & -0.02 & -0.01 & -0.05 \\
CT & 0.00 & 0.0 & 0.20 & 0.00 & -0.09 & -0.01 & -0.02 & -0.05 \\
TO & -0.07 & 0.00 & 0.00 & 0.85 & -0.01 & -0.02 & -0.02 & -0.13 \\
UM & -0.01 & -0.01 & -0.01 & -0.01 & -0.05 & 0.00 & -0.01 & 0.02 \\
FM & -0.10 & -0.01 & -0.01 & -0.01 & 0.00 & 0.20 & -0.15 & -0.15 \\
IM & -0.25 & 0.00 & 0.00 & -0.01 & 0.00 & -0.02 & 0.85 & -0.27
\end{tabular}

Notes: $\mathrm{GN}=$ groundnuts; $\mathrm{RI}=$ rice; $\mathrm{CT}=\mathrm{cotton} ; \mathrm{TO}=$ tobacco; $\mathrm{UM}=$ unfertilised local maize; FM=fertilised local maize; IM=improved maize; FR=fertiliser.

Source: Government of Malawi [1987c].

Once the model has been recalibrated, certain simulation parameters and constraints must be set for the prediction year, for example: ADMARC domestic sales price for crops; ADMARC unit marketing costs for all crops and fertiliser; start of year fertiliser stocks; start of year maize stocks. These parameters and constraints were devised using trend analysis of the previous ten year's data. 'The prediction year parameters and constraints are held constant over all the policy simulations. 
Once the above work has been completed, simulation runs can be carried out using the model's interactive mode. The policy variables which can be changed interactively include:

Producer prices for all the crops

Fertiliser selling price

Fertiliser imports

Tobacco production quota

Weather index

Elasticity set

For each policy scenario fed into the model the model predicts the outcome in terms of the following variables: smallholder production of each crop; ADMARC procurements; ADMARC domestic sales; exports and imports by crop; net balance of payments outcome; net ADMARC cash flow; net SFRF cash flow; change in maize and fertiliser stocks; smallholder and urban real income; and fertiliser leakage to the estate sector.

\section{POLICIES TO BE SIMULATED}

In order to quantify the impact of the SAL agricultural price policy conditionality on Malawi's smallholder sector the policies actually implemented during the SAL programme must be simulated and the results compared with the outcomes of various counter-factual policy simulations. Ministry of Agriculture officials took a strong and well articulated stance against many of the conditions prescribed for the smallholder agricultural sector and this can be used as a basis from which to devise policy counterfactuals for the agricultural sector. Likewise, Bank staff also clearly articulated the price policies they would like to see implemented in Malawi's agricultural sector [World Bank, 1981a].

Three input and commodity price scenarios are simulated on the model. Scenario or Run One uses the actual price policies pursued during the SAL programme which took the form of partial implementation of the Bank's agricultural price conditionality. This involved: maize price increses between 1979.84 in violation of the Bank's condition to improve the relative price of exportable cash crops; a delayed fertiliser subsidy removal programme which did not get underway until 1985; improved compliance between 1985 and 1987 with increases in exportable cash crop prices and fertiliser subsidy removal; and a policy u-tum in 1987 with a large maize price increase and a return to fertiliser subsidies in excess of 20 per cent. Scenario or Run Two represents the government's preferred counter-factual policies of zero compliance with SAL policy conditionality in the agricultural sector. This involved pursuing the food self-sufficiency 
objective with continuous increases in the maize price; only minor increases in exportable cash crop prices such that these crops were implicitly taxed to susidise maize production and distribution; and continued heavy subsidisation of fertiliser. Scenario or Run Three represents the Bank's preferred counter-factual scenario of full compliance with SAL policy reform conditions. This scenario is represented by minimal maize price increases, a rapid increase in export crop prices towards trade parity levels and removal of the fertiliser subsidy by $1984 / 85$. Each scenario consists of a time series of prices covering the cropping seasons 1980/81-1987/88.

The relevant prices under each scenario are fed into the model and the model predicts the outcome for each year in terms of the range of variables as listed in section III. In presenting the results of the exercise those variables which were central to the SAL policy bargaining which took place between the Ministry of Agriculture and Bank staff will be analysed, namely: smallholder production by crop and maize type; maize exports and imports; net balance of payments; net ADMARC cash flows and net SFRF cash flows, which together constitute the net budgetary effect; and smallholder real income.

\section{SIMULATION RESULTS}

\section{Net Budgetary Effect (ADMARC and SFRF Cash Flow)}

The net budgetary effects (Figure 1) of the various policy scenarios are the combined result of policy impact on ADMARC's net cash flow and the net cash flow of the SFRF. A policy of zero compliance with Bank pricing conditionality (Run Two) has a detrimental impact on the government budget throughout the period (Figure 1). Despite the fact that zero compliance involves suppressing the producer price of exportable cash crops (tobacco, groundnuts, and cotton) to levels well below export parity, the resulting profits made by ADMARC on these crop trading activities are insufficient to cover the costs of ADMARC's increased subsidisation of maize production, procurement and distribution under this scenario. Hence, a government policy of placing top priority on food self-sufficiency, via increases in the maize producer price, has a high opportunity cost in the form of worsening of the government budget deficit. Successful Bank opposition to government proposals for a maize price increase in 1985/86 and 1986/87 was based upon the concern that the increases would place an intolerable financial burden on ADMARC's already poor financial state, and would necessitate increased government subventions to the parastatal at a time of extreme budgetary tightness. The modelling result suggest that the Bank's concerns were well founded. 
FIGURE 1

NET BUDGETARY COST SEMULATION RESULTS ( $000 \mathrm{MK} / Y$ )

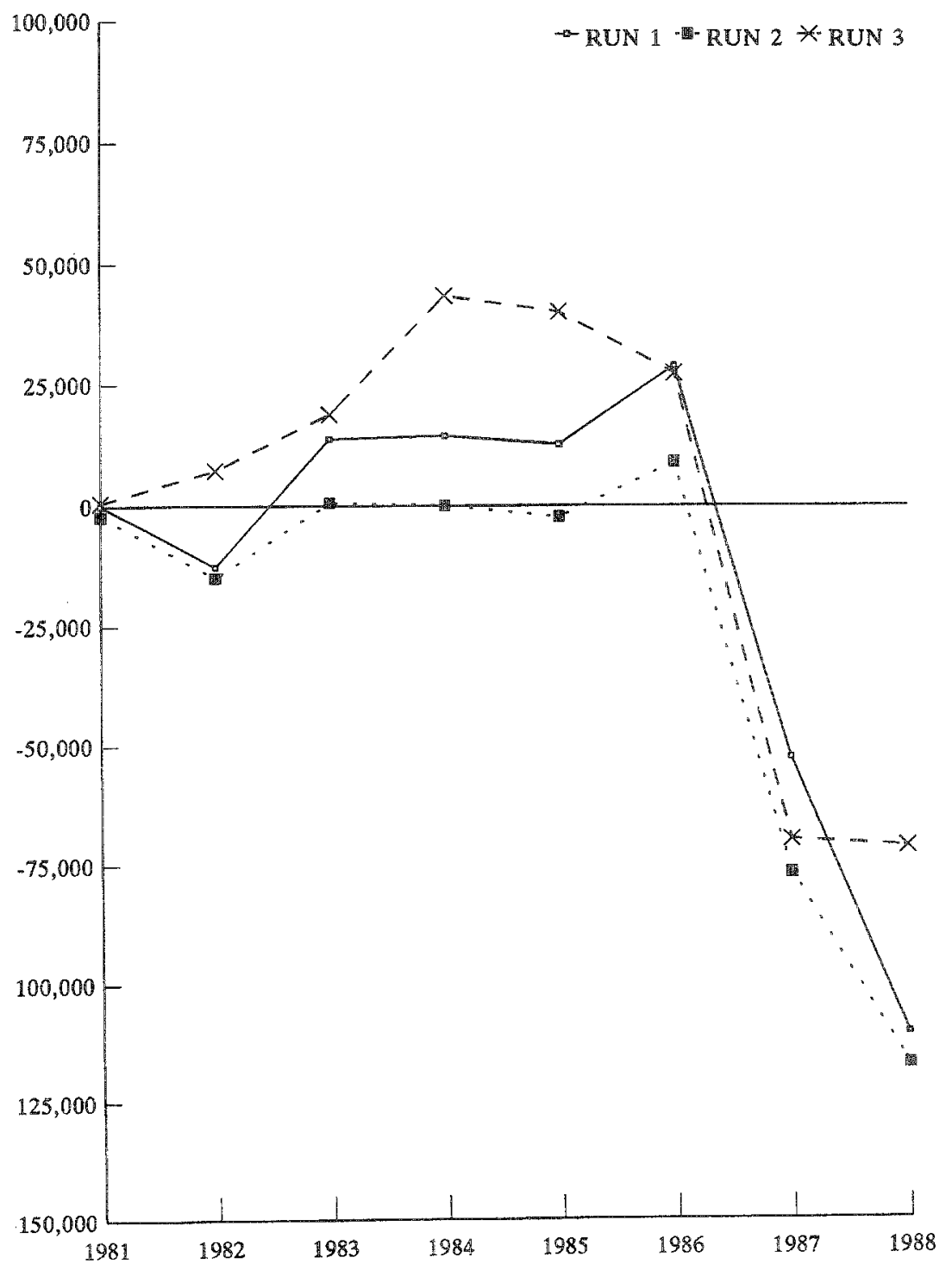

Run $1=$ Partial Compliance, Run $2=$ Zero Compliance and Run $3=$ Full Compliance 
By contrast, the results for Run Three indicate that had the government fully complied with Bank pricing conditionality, this would have produced the most favourable budgetary outcome. ADMARC's net cash flow would have been considerably healthier than was actually the case, that is, under the partial compliance scenario (Run One). Despite the fact that full compliance involves higher producer prices for exportable cash crops in the form of farmgate export parity prices, this is more than offset by ADMARC savings on maize trading activities.

\section{Smallholder Real Incomes}

The zero compliance scenario, placing top priority on food self-sufficiency, also has a detrimental impact on smallholder real incomes (Figure 2). This trend, however, does not begin to emerge until fairly late in the period, that is, 1986 onwards when the zero compliance scenario gives rise to unfavourable smallholder income effects in comparison to both the partial and full compliance scenarios. Between 1986 and 1988, the higher export crop prices under the full compliance scenario more than compensate for the adverse income effects of the scenario's lower maize prices and higher fertiliser prices. However, the fact that the full compliance scenario only gives rise to comparatively favourable income effects in the last three years of the period indicates that the Bank's argument to the effect that parity pricing for both export crops and fertiliser would improve average smallholder income levels was weak.

\section{Smallholder Maize Production}

Analysis of the simulation results in terms of smallholder maize production (Figure 3 ) shows that the modelling results fully support the government's constantly reiterated concern regarding the impact of Bank price policy prescriptions on the focal objective of the country's National Rural Development Plan, namely, increasing maize productivity and production via promoting the uptake of high-yielding maize varieties. Full compliance with Bank pricing conditionality, that is, improving the prices of export crops relative to maize and removing the subsidy on fertiliser, results in the least favourable outcome in terms of both total maize production (Figure 3) and, in particular, improved maize production (Figure 4). In contrast, the government's own first best policy of zero compliance has the most favourable outcome in terms of these two variables.

\section{Exportable Cash Crop Production}

The cost of zero compliance and higher maize production, however, not only takes the form of deterioration in ADMARC's and the SFRF's cash flow, and lower smallholder income levels in latter years, but also lower 
FIGURE 2

SMALLHOLDER REAL INCOME SIMULATION RESULTS (MK/HH/YR)

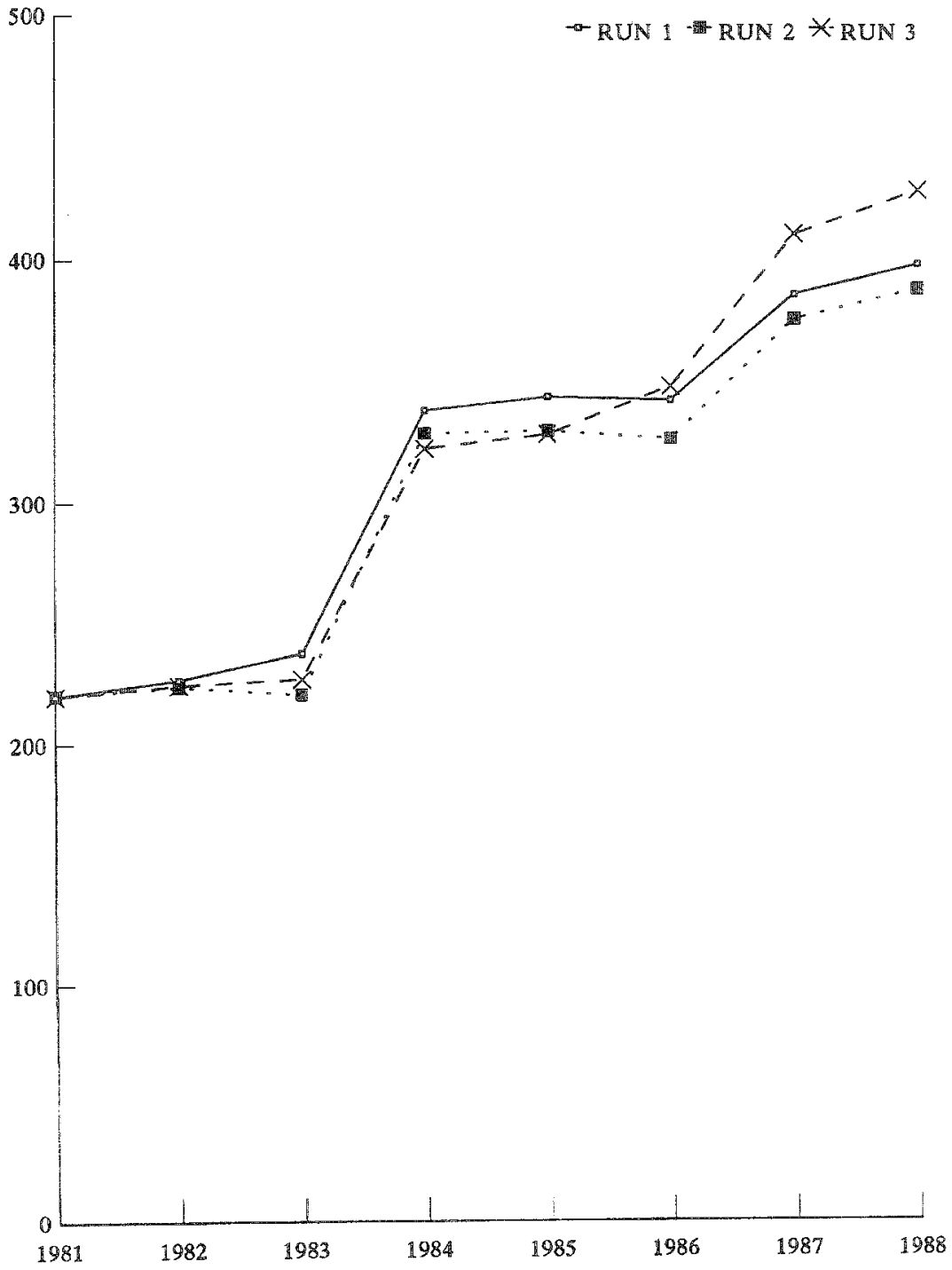

Run 1 = Partial Compliance, Run $2=$ Zero Compliance and $\mathbb{R u n} 3=$ Full Compliance 
FIGURE 3

TOTAL SMALLHOLDER MAIZE PRODUCTION SIMULATION RESULTS $(000 \mathrm{MT} / \mathrm{YR})$

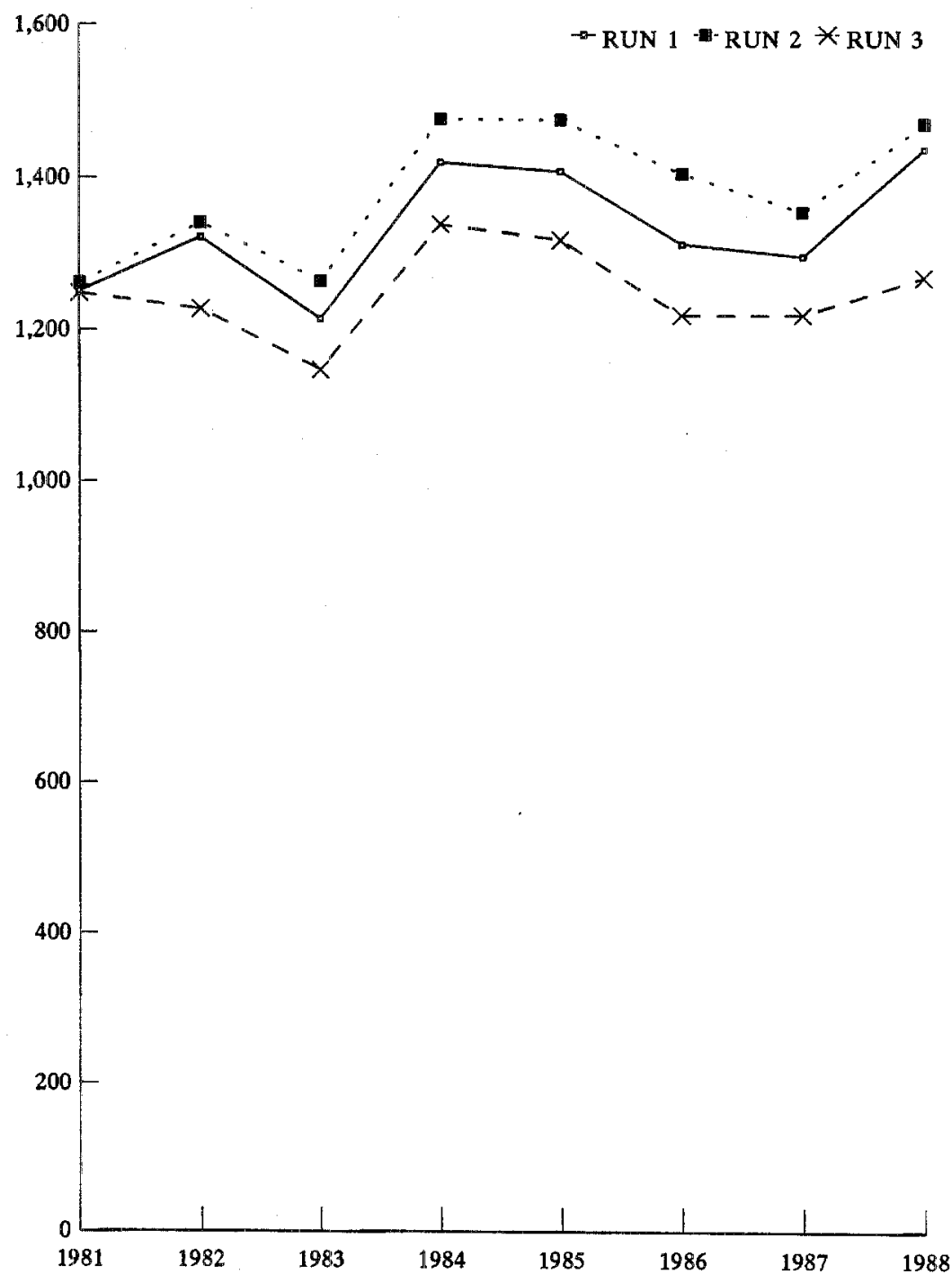

Run 1 = Partial Compliance, Run 2 = Zero Compliance and Run $3=$ Full Compliance 


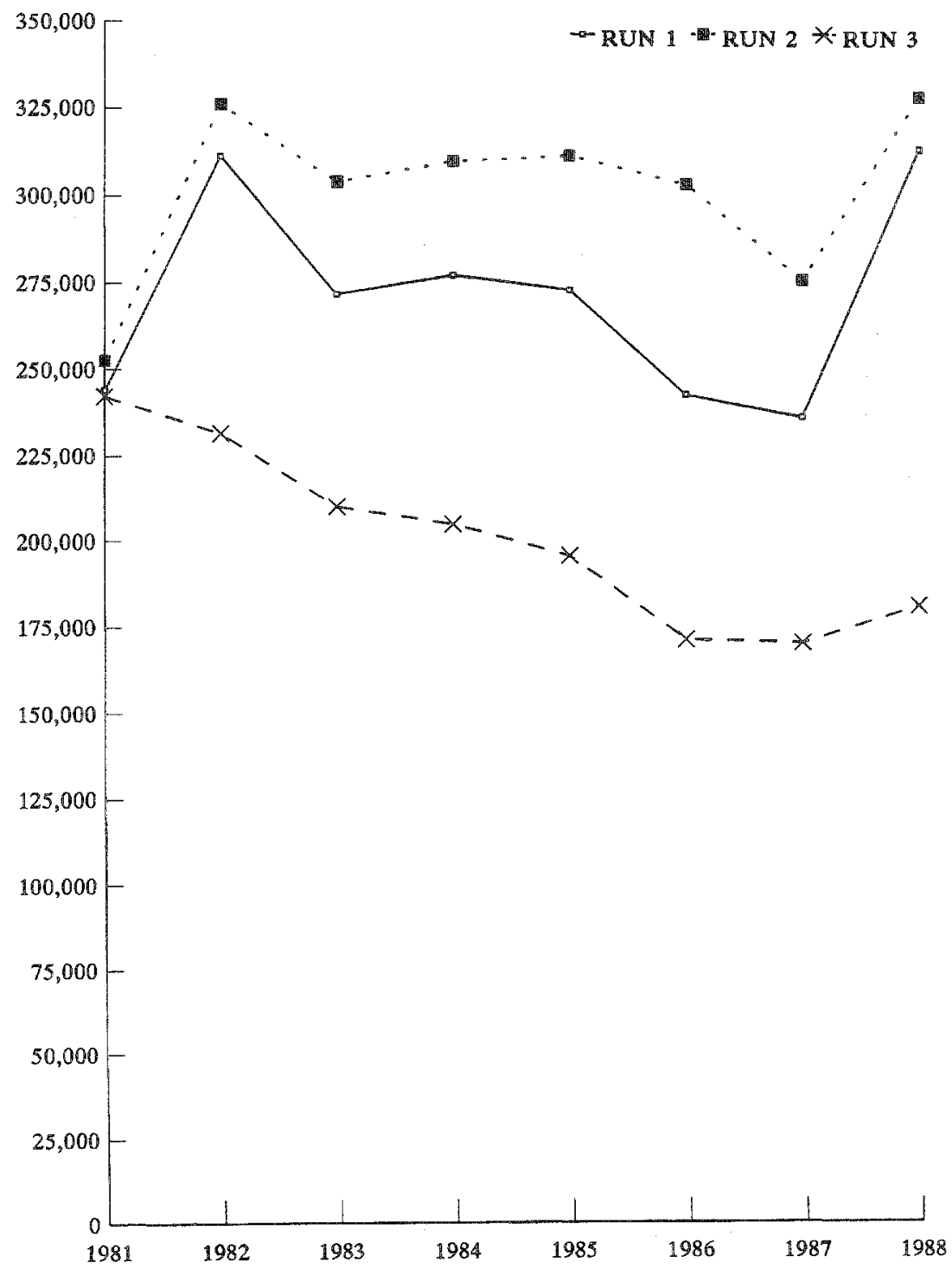

Run $\mathbb{l}=$ Partial Compliance, Run $2=$ Zero Compliance and Run $3=$ Full Compliance 
production of smallholder exportable cash crops (Figure 5). In view of the fact that a central objective of the SAL process was to diversify the country's export base through promotion of smallholder exportable cash crops, the Bank's concern at the low level of prices offered for such crops appears, at first sight, to be reasonable. The Bank's fears were grounded in concern for the effect that a narrowing export base was having on the balance of payments. Indeed, throughout the entire SAL process, the potentially beneficial impact on the balance of payments was used by the Bank as the main justification for the prescription of parity pricing for exportable crops.

\section{The Balance of Payments}

Following the Bank's own line of argument, therefore, the balance of payments becomes one of the main variables by which to judge SAL conditionality on agricultural pricing. The simulation results for this variable produce somewhat mixed results which do not provide unambiguous support for the Bank's line of argument. If we compare the balance of payments outcomes under the full compliance (Run Three) and the zero compliance (Run Two) scenarios, full compliance produces the most favourable outcome in all years except 1986 and 1987 (Figure 6). This provides partial support for the Bank's view that the extra foreign exchange earnings generated by a rapid move towards export parity prices for export crops and the associated production increase of such crops would more than outweigh foreign exchange losses caused by lower maize prices and the associated reduction in maize exports in food surplus years and the increase in maize imports in food deficit years.

On the other hand, the Bank's full compliance scenario compares unfavourably with the partial compliance scenario (Run One) for all years except one (1981). Although the slower move to export parity pricing under the Run One partial compliance scenario reduces foreign exchange earnings from expertable cash crops compared to the Run Three full compliance scenario, this is more than compensated for by the positive effects of higher maize production on the balance of payments. As shown by Figure 7 in most years Run One partial compliance results in lower levels of maize imports in maize deficit years and higher levels of maize exports in maize surplus years compared to Run Three, representing full compliance. These maize trading and balance of payments results which emerge when comparing the outcomes of the partial and full compliance scenarios suggest that the Bank's bargaining position, by which it attempted to convince the government to step-up compliance with SAL agricultural pricing conditionality by promising a favourable relative balance of payments outcome, was misguided. 
FIGURE 5

TOTAL SMALLHOLDER CASH CROP PRODUCTION SIMULATION RESULTS ('DOOMT/YR)

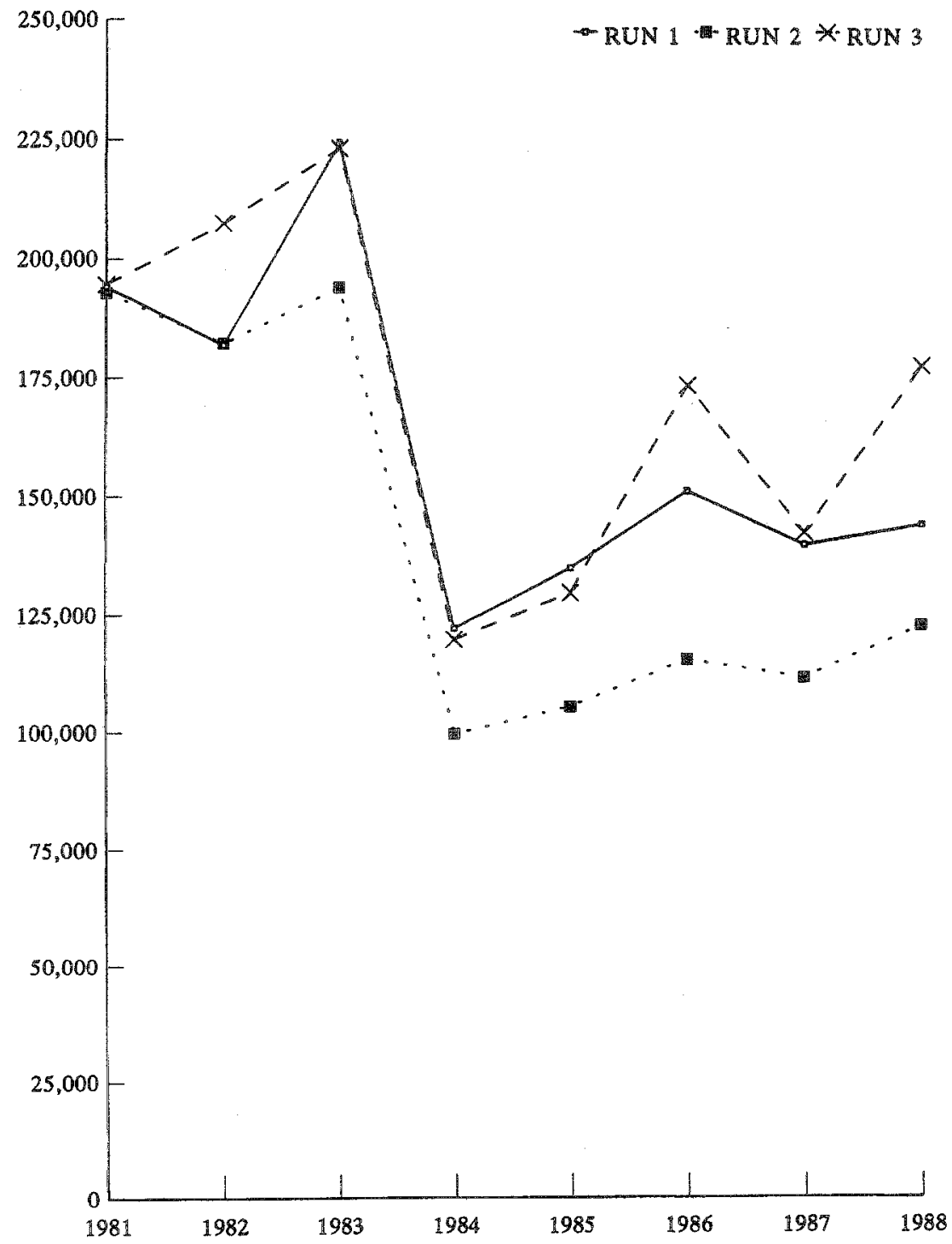

Run $1=$ Partial Compliance, Run 2 = Zero Compliance and Run $3=$ Full Compliance 
FIGURE 6

NET BALANCE OF PAYMENTS SIMULATION RESULTS ('000 MK/YR)

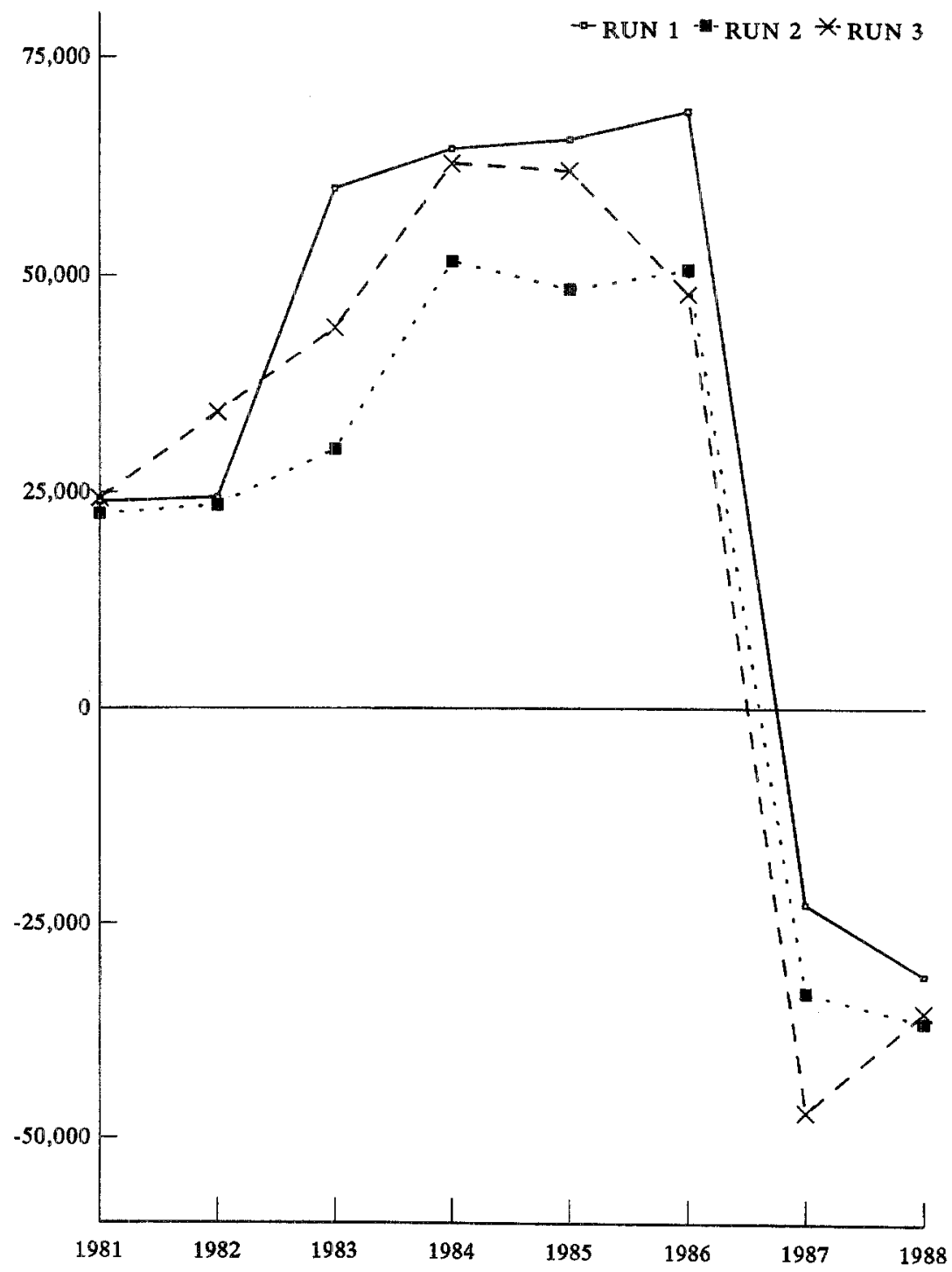


MAIZE EXPORTS SIMULATION RESULTS (-IMPORTS) (MK/YR)

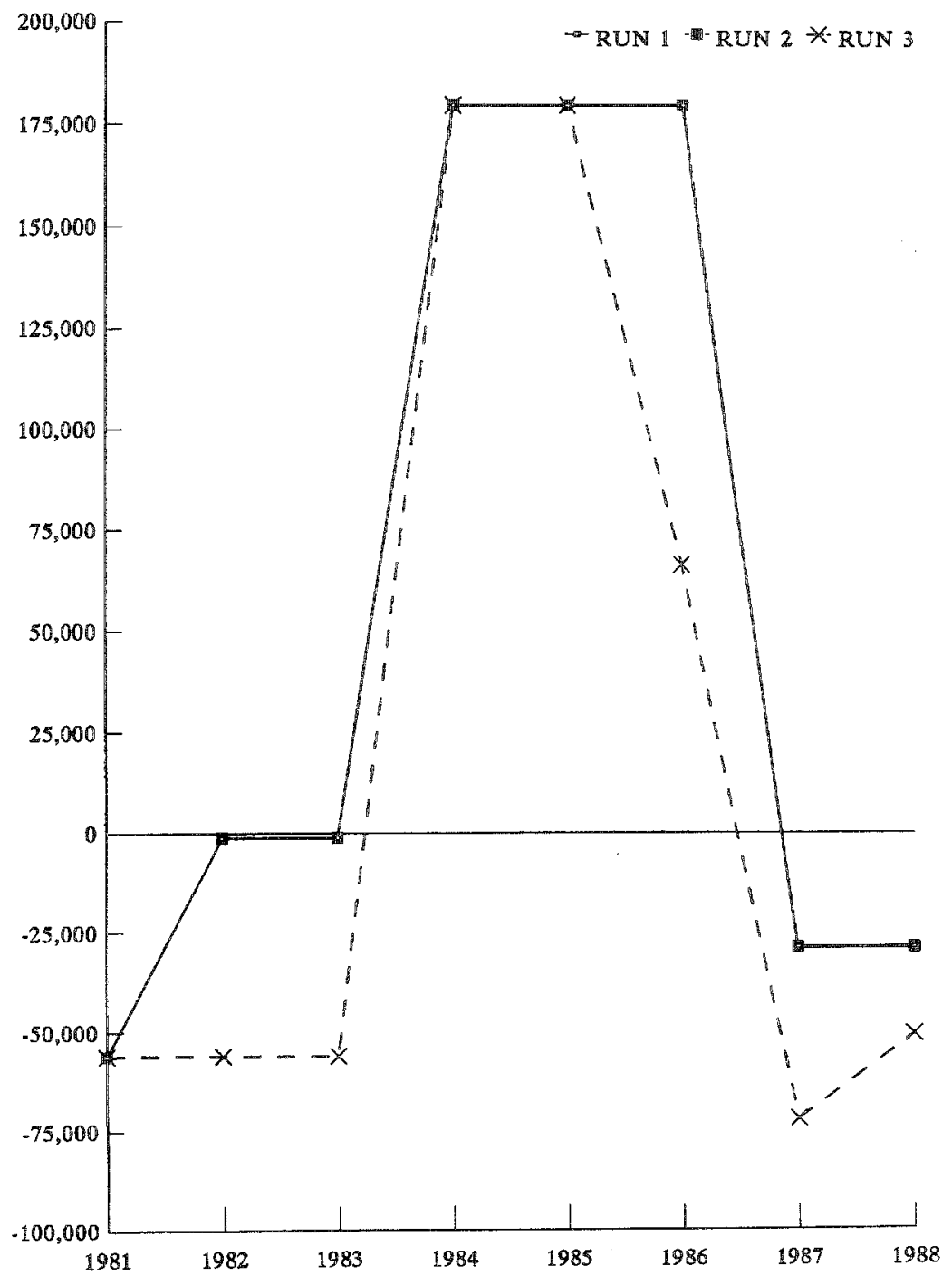

Run $1=$ Partial Compliance, Run $2=$ Zero Compliance and Run $3=$ Full Compliance 


\section{CONCLUSIONS}

The modelling results indicate a clear and unambiguous trade-off between the government's first best pricing policies represented by zero compliance (Run 'Two) and the Bank's first best pricing policies represented by full compliance (Run Three). This takes the form of a trade-off between the country's internal balance (government budget deficit) and the country's food self-sufficiency as measured by smallholder maize production. The nature of this trade-off is depicted in Figure 8. The government's favoured zero compliance policy scenario has advantageous effects on the success of the national food self-sufficiency objective producing the highest level of smallholder maize production. The opportunity cost of this success, however, is a trade-off in the form of a deterioration in the government budget deficit, caused by the need to subsidise both fertiliser sales and maize production, procurement and distribution. On the other hand, the Bank's favoured full compliance policy scenario brings about an improvement in the budget deficit due to the fact that two important parastatals, ADMARC and the SFRF, are allowed to move towards marketorientated pricing policies for fertiliser and maize. The opportunity cost, however, is high in terms of the failure to achieve national food selfsufficiency, with average annual smallholder maize production almost 200,000 tons lower than under the alternative zero compliance scenario (Figure 8).

FIGURE 8

THE BUDGET DEFICIT AND FOOD PRODUCTION TRADE-OFF

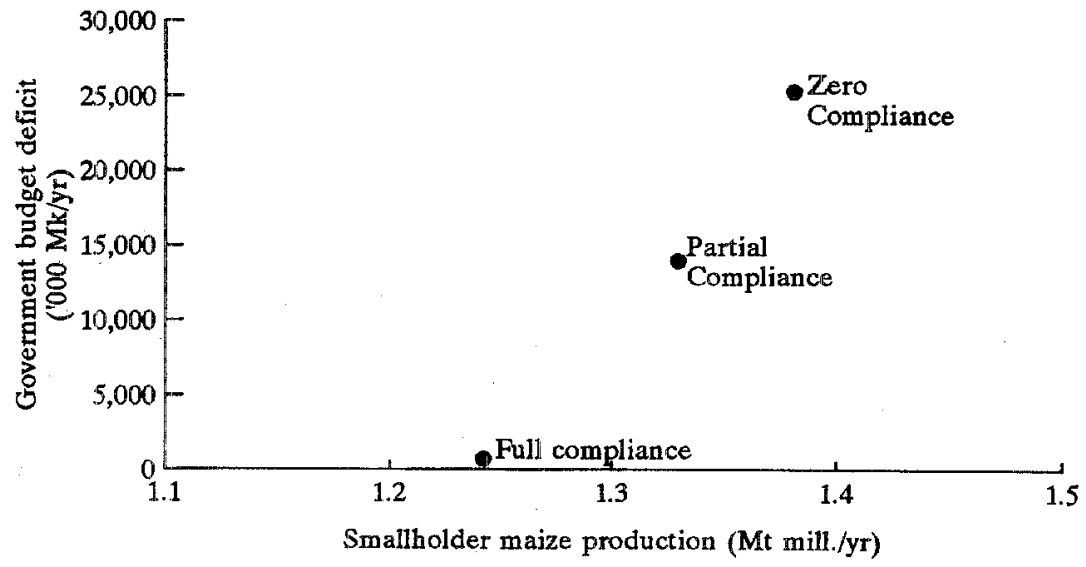

Note: Plots for each policy scenario show the annual average value of each variable for the period 1981-88.

Source: Figures 1 and 3 . 
A policy trade-off also exists between the budget deficit (internal balance) and the balance of payments (external balance) when comparing the partial and full compliance scenarios (Figure 9). Full compliance produces the most favourable government budget outcome but at the cost of a reduction in the balance of payments surplus whilst partial compliance produces the most favourable balance of payments outcome but results in a higher budget deficit.

FIGURE 9

THE INTERNAL/EXTERNAL BALANCE POLICY TRADE-OFF

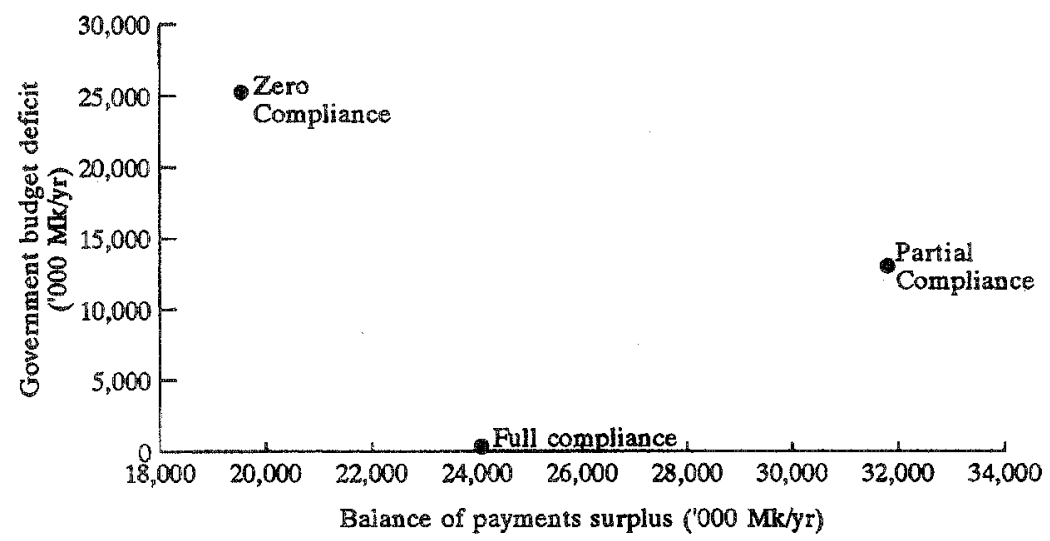

Note: Plots for each policy scenario show the annual average value of each variable for the period 1981-88.

Source: Figures 1 and 6.

The results of the modelling exercise provide evidence in support of the critique of the Bank's agricultural price policies. In particular, they support the argument that suppression of the relative maize producer price and increasing input prices jeopardised any increase in food crop productivity which, in view of Malawi's severe land constraint and land-locked position, was essential if efforts to increase smallholder export crops through price increases were not to take place at the cost of a reduction in food security. Given the food security and balance of payments costs of SAL pricing policies, it is hardly surprising that the prices announced by the Government for the $1987 / 88$ growing season involved a complete policy u-turn back to the government's own pre-SAL pricing policies. The producer price of maize was increased by 36 per cent, improving the crop's attractiveness in relation to exportable cash crops, and fertiliser prices resulted in a subsidy of over 20 per cent, corresponding to the level of subsidies in the pre-SAL era. 
It is interesting to note that in the late 1980s the Bank also began to revise its position on agricultural price policies in the Sub-Saharan region in a manner which concurs with the critique and the results produced by this modelling exercise. Whereas the 1981 Berg report stated that: 'If export crop prices rise, it is feared that food crop production will fall. This is, however, not necessarily so, and even if export crop output were to grow at the expense of food crop production, it is not necessarily bad' [World Bank, 1981b: 62]. By 1990 this view had been reversed: 'The nutritional implications of extensive switching of production away from non-tradable food crops into export crops has impeded adjustment' [World Bank, 1990b: 59].

In the structuralist world removal of structural constraints via investment and other non-price policies is seen as an essential pre-requisite for sustained growth in response to adjustments in price incentives. In the second half of the 1980 s this was the very view being articulated by members of the Bank's own staff such as Cleaver [1985] and Lele [1989] in the context of adjustment in Sub-Saharan African, particularly in the agricultural sector. This position was reinforced by many of the papers produced for the Bank's research study 'Managing Agricultural Development in Africa' (MADIA). For example, Christiansen and Southworth's paper on Malawi for the study came to the following conclusion:

The disappointing response to changes in output pricing policy mirrors experience elsewhere in Africa that suggest that price factors - although important - are not the only ones affecting agricultural production. The farmers' ability to increase productivity in response to changing prices hinges critically on timely access to inputs, the availability of appropriate technology and reliable output marketing arrangements. In Malawi, these non-price factors currently appear to be binding constraints... The same factors that impede a significant aggregate output response also affect food security [Christiansen and Southworth, 1988: 11].

An analysis of the policy bargaining between the Bank and the Government throughout the duration of Malawi's three SALs indicates that neither party was fully aware of the nature of the policy trade-offs revealed by this modelling exercise. The Bank, for example, devoted little effort to analysing the adverse causal links which existed between its parity pricing policy prescriptions and the policy objective of national food selfsufficiency, regarding which the government constantly expressed its concern. This reflects the relatively low priority given to the food production objective by the Bank as compared to Malawi's own political directorate. As a result, the Bank continued to channel large amounts of 
project aid into Malawi's National Rural Development Plan (NRDP), whilst at the same time pursuing programme aid conditionality which ran counter to the focal objectives of the plan, namely, the achievement of food selfsufficiency at both the individual and the national level.

This inconsistency between the Bank's role as a programme aid donor and its role as a traditional project aid donor is not unique to Malawi. Similar conflicts have been identified in the agricultural sectors of other low income agrarian economies [Mosley, Harrigan and Toye, 1991, Vol.1]. Neither was it vable for the Eank to defend its price policy prescriptions by arguing that the adverse effect on food self-sufficiency could be overcome by using increased foreign exchange earnings from exportable cash crops to achieve food security via maize imports. The modelling results show that full compliance with Bark policy prescriptions would not have been the most efficient way to purste such a food security strategy since the partial compliance scenario generates a healthier outcome in terms of both food production and balance of payments. Hence, although the Bank was contect to stress the beneficial effects of its prescribed policies in terms of the pollicy objective of reducing the government's budget deficit it failled to acknowledge the opportunity costs un terms of other policy objectives relating to the balance of payments, success of WRDP project aid and food security when compared to altemative policy scenarios which could have been pursued.

The government, for its part, advocated pricing policies which were complementary to much of the country's project aid in the smallholder agricultural sector, but which placed a high demand on scarce budgetary resources. Seldom was there a clear acceptance, particularly on the part of the Ministry of Agriculture, of the magnitude of these budgetary costs, either directly, in tems of the necessary govemment subventions to ADMARC and the SFRF, or indirectly, in the form of government resources foregone in other areas of public economic activity.

Had the government and Bank been more aware of trade-offs between competing policy objectives, perhaps greater joint effort would have been devoted to devising policies with the potential to reduce the severity of the trade-offs. For example, given the government's desire to follow policies which complemented the NRDP objective of increasing food crop productivity, greater effort could have been made by both parties to devise new measures aimed at reducing the budgetary strain caused by these policies. Various budgetary cost reduction options existed in terms of improvements in the commercial efficiency of both ADMARC and the SFRF which would have reduced net government subventions to the two parastatals. The NRDP itself was also in need of considerable budgetary scrutiny in order to identify areas where recurrent costs could be reduced 
without impeding project productivity. This, however, would have involved difficult decisions within the Bank, since past Bank project aid to the NRDP had created an extensive, nation-wide agricultural development project with high budgetary costs. Finally, there was a strong case to be made for policies aimed at increasing tax revenues from the agricultural sector. In particular, the tax potential of the estate sub-sector remained largely untapped.

It is encouraging to note that in the late 1980 s and early 1990 s, policies along the above lines, which move beyond a narrow pricist approach to adjustment and tackle some of the constraining structural features of Malawian agriculture, began to emerge. Both the government and the Bank began to show a greater awareness of the need to reduce the budgetary costs of the food security objective [World Bank, 1989a]. In the late 1980s the government established a Food Security Unit in the Office of the President and Cabinet, one of its tasks being to review the costs of the country's strategic food reserve. The Statement of Development Policies, 1987-1997 [Government of Malawi, 1987a] acknowledged the need to tackle the issue of taxation in the estate sector and represented the first domestic policy initiative to broach this politically sensitive issue. The Bank for its part launched its own extensive study of the scope, costs and results of the NRDP [World Bank, 1989c]. Finally, improving the commercial efficiency of ADMARC formed a major objective of the Bank's Agricultural Marketing Froject in Malawi which was launched in 1990 [World Bank, 1990b].

final version received November 1996

\section{NOTES}

1. This contrasts with the situation for the Bank's traditional activity of project lending where sophisticated cost-benefit analysis has generated a multiplicity of results in terms of evaluating project impact.

2. The relative pros and cons of each method have been discussed in detail in [Goldstein, 1986; Harrigan and Mosley, 1991; McGillivray, 1995].

3. SAL I provided US\$45 million and ran from January 1981 to June 1983; SAL II provided US\$52 million and ran from November 1983 to November 1985; SAL III provided US\$70 million and ran from December 1985 to December 1987.

4. Other significant SAL reforms included: restructuring of Press Holdings Ltd., the President's giant personal holding company; restructuring of various parastatals; liberalisation of consumer price controls; and tax increases and public expenditure reductions to reduce the budget deficit. Harrigan 1995 and Pryor 1990 provide a comprehensive review of the adjustment loans.

5. Structural constraints facing smallholders inclided: inadequate land [Christiansen and Southworth, 1988; Lele, 1988; Lele and Meyers, 1987]; legal restrictions on what crops smallholders could grow [Cromwell, 1992; Harrigan, 1988]; formal credit constraints; seasonal labour shortages; inadequate fertiliser up-take; limited coverage and inadequate content of extension work; inadequate market and transport infrastructure [Cromwell, 1992]; and insufficient research effort to develop high yielding maize varieties acceptable to smallholders. 


\section{REFERENCES}

Ahn, C., Singh, I. and L. Squire, 1981 'A Model of an Agricultural Household in a Multicrop Economy: The Case Of Korea', Review of Economics and Statistics, Nov.

Bamum, H. and L. Squire, 1979, 'A Model of an Agricultural Household: Theory and Evidence', World Bank Staff Occasional Paper, No.27, Johns Hopkins University Press.

Chalira, Z., 1993, 'Malawi's Structural Adjustrnent Progranme, 1981-1990: An Evaluation of the Impace of External Factors and Programme Design on Programme Performance', Ph.D. thesis, Faculty of Economic and Social Studies, University of Manchester.

Christiansen, R. and V. Sowthworth, 1988, 'Agricultural Pricing and Marketing Policy in Malawi: Implications for a Development Strategy', paper prepared for the World Bank's research study on 'Managing Agricultural Development in Africa' (MADIA) and presented at the Symposium on 'Agricultural Policies for Growth and Development', Mangochi, Malawi, 31 Oct.-4 Nov. 1988.

Cleaver, $\mathbb{K}$., 1985, "The Impact of Price and Exchange Rate Policies on Agriculture in StbSaharan Africa', World Bank Staff Working Paper 728, Washington, DC: World Bank.

Cromwell, E., 1992, 'Malawi', in A. Duncan and J. Howell (eds), Structural Adjustment and the African Farmer, London: James Currey.

Goldstein, M., 1986, The Globat Effects of Fund-Supported Adjustment Programmes, Occasional Paper 42, Washington, DC: IMF.

Government of Malawi, 1987a, Statement of Development Policies 1987-96, Zomba: Government Printer.

Government of Mallawi, $1987 \mathrm{~b}$ 'An Analysis of Pricing Options Using the World Bank Agriculural Pricing Model', unpublished paper prepared by $C$. Jones (Consultant) and $G$. Mulaga (EPD), Lilongwe, 2 July 1987.

Harrigan, 3., 1988, 'Malaw: The Impact of Pricing on Smallholder Agriculture 1971-1988', Development Policy Review, Vol.6, pp.415-33.

Harrigan, J., 1991 'Malawi', in P. Mosley, J. Harrigan. and J. Toye, Aid and Power: The World Bank and Policy-Based Lending, Vol.II, London: Routledge.

Harrigan, J., 1995, "World Bank Policy-based Lending: The Case of Malawi's Three Structural Adjustment Loans", Ph.D. thesis, Faculty of Economic and Social Studies, University of Manchester.

Harrigan, J. and P. Mosley, 1991, 'Evaluating the Impact of World Bank Structural Adjustment Lending: 1980-87', Journal of Development Studies, Vol.27, No.3, April (Speciall Issue).

Harrigan, J, and P. Mosley, 1992, 'Evaluating the Impact of World Bank Structural Adjustment Lending: 1980-87', in L. Berlage and O. Stokke (eds.), Evaluating Development Assistance: Approaches and Methods (EADI Book Series 14), London: Frank Cass.

Kirchner, J., Singh, I. and L. Squire, 1985 Agricultural Pricing and Marketing Policies in Malawi: A Multi-Market Analysis, CPD Discussion Paper, Washington, DC: World Bank.

Kraaij, $F$ van der, 1994, 'Backgroulad notes on Sub-Saharan Africa', in $R$. van der Hoevan and $F$. van der Kraaij (eds.), Structural Adjustment and Beyond in Sub-Saharan Africa, London/Pontsmouth: James Currey/Heinemann.

Kydd, I. and R. Christiansen, 1982 'Structural Change in Malawi since Independence: Consequences of a Development Strategy Based on Large Scale Agriculture', World Development, Vol. 10, No.5, pp.355-75.

Kydd, J. and $A_{\text {. }}$. Hewitt, 1986, 'The Effectiveness of Structural Adjustment Lending: Initial Evidence from Malawi', World Development, Vol.24, No.3, pp.347-65.

Lele, U., 1988, 'Structural Adjustment, Atgricultural Development and the Poor: Some Lessons from the Malawian Experience', paper presented at the Symposium on Agricultural Policies for Growth and Development, Mangochi, Malawi.

Lele, U., 1989, Agricultural Growth, Domestic Policies, the External Environment and Assistance to Africa: Lessons of a Quarter Century, Washington, DC: World Bank.

Lele, U. and L. Meyers, 1987, Growth and Structiral Change in East Africa: Domestic Policies, Agricuttural Perfornance and Wortd Bank Assistance, 1963-86, Washington, DC: World Bank.

Litte, I.M., 1982, Economic Development: Theory, Policy and International Relations, New 
York: Basic Books.

McGillivray, M., 1995, 'Methodological Issues in Evaluating the Economic Effects of Adjustment Programmes: A Survey of Econometric Approaches', paper presented at the 4th SAF Workshop, 5-7 Jan. 1995, University of Nottingham.

Mosley, P., 1987, Conditionality as a Bargaining Process: Structural Adjustment Lending 1980-86 (Princeton Essays in International Finance, No.168), Princeton, NJ.

Mosley, P., Harrigan, J. and J. Toye, 1991, Aid and Power: The World Bank and Policy-Based Lending, Volumes $I$ and $I I$, London: Routledge.

Pryor, F., 1990, The Political Economy of Poverty, Equity and Growth: Malawi and Madagascar (World Bank Comparative Study Series), Oxford: Oxford University Press.

Sahn, D., Arulpragasam, J. and L. Merid, 1990, Policy Reform and Poverty in Malawi: A Survey of a Decade of Experience, Cornell Food and Nutrition Policy Programe, Monograph 7, Dec.

World Bank, $1981 \mathrm{a}$, Report and Recommendation of the President of the International Bank for Reconstruction and Development to the Executive Directors on a Structural Adjustment Loan to the Republic of Malawi, Report No.P-3024a-MAI: Washington, DC.

World Bank, 1981b, Accelerated Development in Sub-Saharan Africa: An Agenda for Action, Washington, DC.

World Bank, 1983, 'Malawi: Fertilizer Policy Analysis', a note prepared for the Government of Malawi by a World Bank Mission, 19 June, unpublished paper.

World Bank, 1984a, 'Agricultural Price Policy Analysis in the Eastern African Region: An Approach Paper', discussion draft, I.J. Singh (EANEM), Eastern African Region, Washington, DC.

World Bank, 1984b, 'Agricultural Fricing and Marketing Policies in Eastern Africa: Developing a Framework for Analysis' (I. Singh, L. Squire and J. Kirchner), unpublished paper, Washington, DC.

World Bank, 1984c, 'Malawi: Agricultural Pricing Model: Policy Issues for Simulation', unpublished paper (I.J. Singh (EANEM) and L. Squire (CPDRM)), Washington, DC.

World Bank, 1984d, Malawi: Agricultural Pricing Model: Alternative Policy Scenarios and Their Inplications', unpublished draft paper (I.J. Singh, L. Squire and J. Kirchner), Washington, $\mathrm{DC}$,

World Bank, 1988, Report on Adjustment Lending, document $\mathbb{R} 88-199$, World Bank Country Economics Department, Washington, DC.

World Bank, 1989a, Malawi: Food Security Report, Report No.8151-MA1, Washington, DC.

World Bank, $1989 \mathrm{~b}$, Malawi Third Structural Adjustment Operation Credits 1644-MAI and A-9, Project Completion Report, Draft, June 1989, Washington, DC.

World Bank, 1989c, Malaw National Rural Development Plan Technical issues Review, Report No.7539-MAI, Washington, DC.

World Bank, 1990a, Malawi: Growth Through Poverty Reduction, Report No.8140-MAI, Washington, DC: World Bank.

World Bank, 1990b, Report and Recommendation of the President of the International Development Association to the Executive Directors on a Proposed Credit of SDR 52.6 million (US $\$ 70.0$ million equivalent) to the Republic of Malawi for an Agricultural Sector Adjustment Programme, Report No.P-5189-MAI, Washington, DC.

World Bank, 1994, Adjustment in Africa: Reforms, Results, and the Road Ahead, A World Bank Policy Research Report, New York: Oxford University Press.

Yotopoulous, P. and L. Lau, 1974, 'On Modelling the Agricultural Sector in Developing Countries: An Integrated Approach to Micro and Macroeconomics', Journal of Development Economics, Vol.1., No.2, pp.105-27. 
Copyright of Journal of Development Studies is the property of Routledge and its content may not be copied or emailed to multiple sites or posted to a listserv without the copyright holder's express written permission.

However, users may print, download, or email articles for individual use. 